\title{
Prevalence of transmissible viral disease in maternal blood samples of autologous umbilical cord blood in a private cord blood bank
}

\author{
Juthatip Fongsarun', Maneerat Ekkapongpisit ${ }^{2}$, Mantana Paisan ${ }^{3}$, Siripen Chanthachorn ${ }^{3}$ and Konstantinos I Papadopoulos ${ }^{4 *}$ \\ *Correspondence: kostas@thaistemlife.co.th \\ ${ }^{1}$ Medical Director, THAI StemLife, Thailand. \\ ${ }^{2}$ Laboratory Director, THAI StemLife, Thailand. \\ ${ }^{3}$ Laboratory Technician, THAI StemLife, Thailand. \\ ${ }^{4}$ Chief Research and Development, THAI StemLife, Thailand.
}

\begin{abstract}
Background: To provide information on the prevalence of transmissible viral disease in a Thai cohort of 2101 consecutive maternal blood samples of autologous umbilical cord blood (UCB) stored in a private cord blood bank.

Materials and methods: Transmissible viral disease screening in 2101 consecutive maternal blood samples was performed serologically using the CMIA technique on an Architect i1000SR for Hepatitis B Virus (HBV) (HBsAg and Anti-HBc), Hepatitis C Virus (HCV) (anti-HCV), Human Immunodeficiency Virus (HIV) (HIV Ag/Ab Combo), Human TLymphotropic Virus type 1 and 2 (HLTV 1/2) (Anti-HTLV 1/2) and Cytomegalovirus (CMV) (CMV-IgG and CMV-IgM). Nucleic Acid Tests (NAT) were used as confirmatory tests for HBV, HIV and HCV. The prevalence of transmissible viral disease and comparisons between serological screening and NAT testing were studied and reported in this study.

Results: In 2101 consecutive maternal serum samples, the positive rate of HBV-NAT was $1.62 \%$, HCV-NAT was $0.14 \%$, HIVNAT was $0 \%$, HBsAg was $2.52 \%$, anti-HBc was $16.85 \%$, anti-HCV was $0.33 \%$, and $\mathrm{HIV} \mathrm{Ag/Ab} \mathrm{combo} \mathrm{was} \mathrm{borderline} \mathrm{but}$ finally negative in one case. In HBsAg positive samples the positive rate of HBV-NAT was $64.15 \%$ while in anti HBc positive samples, the positive rate of HBV-NAT was 9.6\%. In anti HCV positive samples, the positive rate of HCV-NAT was $42.86 \%$. The positive rate of HTLV $1 / 2$ was $0 \%$ and borderline in $0.19 \%$ but finally reconfirmed negative in all cases. The positive rate of CMV-IgG was $86.53 \%$ while CMV-IgM was $0.33 \%$.

Conclusions: In the present study, in a Thai cohort of maternal blood samples of autologous UCB stored in a private cord blood bank, very low prevalence of transmissible viral disease was noted. HBV, HCV and CMV prevalences were lower than observed in the general Thai population, possibly due to widespread of vaccine immunization, and the higher socioeconomic status of the mothers opting for private UCB banking. Due to our screening procedures, HIV could not be detected in any of the maternal sera. HTLV 1/2 could not be detected in any of the samples and this is the first report of its prevalence in Thailand in almost 20 years. The low prevalence of CMV IgM reinforces UCBs advantage in HSCT. The molecular biology techniques would make up for the default of the serological methods.
\end{abstract}

Keywords: Thailand, umbilical cord blood, stem cells, transplantation, transmissible viral disease, maternal blood, CMV, HCV, HBV, HIV, HTLV I/II, NAT, cord blood banking

\section{Introduction}

Umbilical cord blood (UCB) being very rich in hematopoietic progenitors is increasingly being used as an alternative source of hematopoietic stem cells (HSCs) in conventional autologous and (related and unrelated) allogeneic transplants (HSCT) in children and increases in adults $[\mathbf{1 , 2}]$. The lower immunological reactivity of its lymphocytes allows some degree of HLA incompatibility with the recipient, correspondingly, the incidence and intensity of graft-versus-host disease (GVHD) is lower in patients who have received a UCB transplant $[1,2]$. Other advantages of using HSCs from UCB are prompt availability, no risks to the mother or newborn at collection, low risk of transmissible viral infection, absence of donor attrition and immense donor reservoir, along with better recruitment of ethnic minorities [2]. Banked unrelated donor UCB in public banks has improved access to hematopoietic stem cell transplantation for patients without a suitably matched donor with almost $20 \%$ of HSCT being obtained from unrelated donors [3] while in the remaining $80 \%$, autologous or related (sibling) allogeneic sources are employed [3] with significantly lower costs for the two latter compared to the former [4]. Moreover, in view of the recent evidence of UCB's HSC plasticity and the strong evidence supporting the concept that HSCs are pluripotent and the source for the majority, if not all, of the cell types in our body [5], autologous and related allogeneic UCB stem cell storage offers an opportunity for many families for use in future regenerative medical purposes $[6,7]$. Increasing use of preimplantation genetic diagnosis (PGD) with HLA matching and subsequent related allogeneic cord blood HSCT in Thalassemia [8,9], endemic in South East Asia, and other hereditary conditions [8] and along with favourable support for autologous UCB use in cerebral palsy $[10,11,12,13]$, traumatic and/or hypoxic brain injury $[14,15]$, diabetes [6,7], and deafness $[6,7]$ has already started transforming the field of UCB banking. 
Fongsarun et al. Transplantation Technology 2013,

http://www.hoajonline.com/journals/pdf/2053-6623-1-1.pdf

Table 1. List of viral marker screening tests and positive cut off value of each test at THAI StemLife Laboratory.

\begin{tabular}{lll}
\hline Viral Pathogen & $\begin{array}{l}\text { Viral Markers } \\
\text { (Test Name) }\end{array}$ & $\begin{array}{l}\text { Positive } \\
\text { Cut off Value }\end{array}$ \\
\hline $\begin{array}{l}\text { Hepatitis B Virus (HBV) } \\
\text { Hepatitis B Virus (HBV) }\end{array}$ & Anti-HBc & $\mathrm{S} / \mathrm{CO} \geq 1.00$ \\
$\begin{array}{l}\text { Hepatitis C Virus (HCV) } \\
\text { Human Immunodeficiency }\end{array}$ & Anti-HCV & $\mathrm{S} / \mathrm{CO} \geq 1.00$ \\
$\begin{array}{l}\text { Virus (HIV) } \\
\text { Human T- Lymphotropic Virus } / \mathrm{Ab}\end{array}$ & $\mathrm{S} / \mathrm{CO} \geq 1.00$ \\
$\begin{array}{l}\text { Cype I and II (HLTV I/II) } \\
\text { Cytomegalovirus (CMV) }\end{array}$ & CMV IgG & Concentration value \\
& & $\geq 6.0$ AU/ml \\
Cytomegalovirus (CMV) & CMV IgM & $\begin{array}{l}\text { Concentration value } \\
\end{array}$ \\
\end{tabular}

Viral disease (VD) markers including hepatitis B (HBV) and $\mathrm{C}(\mathrm{HCV})$, human immunodeficiency virus (HIV), human T-lymphotropic virus Types 1 and 2 (HTLV 1/2), and cytomegalovirus (CMV) are screened in all maternal blood samples of every UCB sample collected and stored on our premises as part of our quality control dictated by international guidelines and according our Accreditation Standards.

Since one of the main advantages of UCB is a decreased risk of transmissible viral infections, the aim of the present study was to document the prevalence of VD in a cohort of Thai mothers that have elected autologous UCB storage for their offspring.

\section{Materials and methods Sample collection}

UCB banking is a multidisciplinary program involving, obstetricians, nurses, medical technologists, administrative staff, and other professionals. Maternal blood samples were collected from 2101 consecutive mothers who elected autologous UCB storage for their offspring with THAI StemLife after having signed informed consent. The overwhelming majority of the maternal blood samples were collected by a THAI StemLife registered nurse attending the mother during the intravenous (IV) line insertion at the time of hospital admission and before delivery. Maternal serum was collected using standard hospital procedures in two $4 \mathrm{ml}$ blood collection tubes while maternal plasma, was collected in a $6 \mathrm{ml}$ venous blood collection tube. All samples were kept at $5-25^{\circ} \mathrm{C}$ in validated temperature control box (THAI StemLife Laboratory) equipped with a calibrated temperature logger (ESCORT Intelligent Mini, Escort Inc., NJ, USA) and transported to THAI StemLife Laboratory together with the collected umbilical cord blood immediately after collection by dedicated THAI StemLife logistics staff. Evaluation of blood sample quality was performed and recorded by a resident medical technologist upon sample arrival. In case of a maternal blood sample not conforming to quality controls, a new collection was performed 24 hours after withdrawal of the intravenous infusion.

\section{Viral marker screening tests}

The maternal serum samples were loaded in sample carriers and loaded to the Architect $i 1000 \mathrm{SR}^{\circledast}$ machine (Abbott Diagnostics, Abbott Park, IL, USA). The viral marker screening tests were performed using Abbott commercially available infectious markers in vitro diagnostic reagents as recommended by manufacturer. A list of infectious markers performed on site at the ISO 15189 accredited THAI StemLife Laboratory are shown in Table 1. Samples with reactive results for HIV Ag/Ab combo, HBsAg, anti-HCV, anti-HTLV 1/2 or CMV IgM were confirmed by repeated testing and/or subjected to further diagnostic testing at a reference laboratory.

\section{Nucleic Acid Test (NAT Test)}

Screening NAT were performed individually on each plasma sample using the Procleix ${ }^{\oplus}$ Ultrio ${ }^{\circledR}$ Assay (Genprobe Incorporated, San Diego, CA) with Procleix ${ }^{\circledR}$ Tigris or Procleix ${ }^{\circledast}$ System. Samples in which reactive screening results were found are further tested with HIV, HBV, and HCV discriminatory assays.

\section{Data collection and Statistical analysis}

All sample information and results were recorded in THAI StemLife's customized Microsoft Dynamic NAVISION, Version 5.0 database system (NaviWORLD, TH). Statistical analyses were performed using Microsoft Excel version 2007.

\section{Results}

Overall, 2101 consecutive maternal blood samples in a cohort of Thai mothers that have elected autologous UCB storage for their offspring were tested.

\section{Hepatitis B virus (HBV)}

The prevalence of $\mathrm{HBsAg}$, anti-HBc, HBV-NAT positive were $2.52 \%(53 / 2101), 16.85 \%$ (354/2101), and 1.62\% (19/2101) respectively. Every sample that reacted to $\mathrm{HBsAg}$ also reacted to anti-HBc, and there were 301 samples with positive reactivity to anti-HBc only. In those samples that anti $\mathrm{HBC}$ was positive, the positive rate of HBV-NAT was 9.6\% (34/354) while in HBsAg positive samples the positive rate of HBV-NAT was $64.15 \%$ (34/53) (Table 2). All samples negative for HBsAg and anti-HBC were also negative in HBV-NAT (Table 2). There was no sample that was solely reactive to HBV-NAT.

\section{Hepatitis $\mathrm{C}$ virus (HCV)}

The prevalence of Anti-HCV and HCV-NAT positivity was $0.33 \%(7 / 2101)$ and $0.14 \%$ 93/2101) (Table 2). In the anti-HCV positive samples, the positive rate of HCV-NAT was $42.86 \%$ (3/7). All anti-HCV negative samples were also negative to HCV NAT. There was no sample that was solely reactive to HCV-NAT. Follow up HCV NAT was advised to all anti-HCV positive/HCV-NAT negative mothers and repeat HCV-NAT 
Fongsarun et al. Transplantation Technology 2013,

Table 2. Viral marker serological screening test results from maternal sera and correlation between micro-particle immunoassay and nucleic acid amplification (NAT) testing results.

\begin{tabular}{|c|c|c|c|c|}
\hline \multirow[b]{2}{*}{ Test } & \multicolumn{2}{|l|}{ Serology } & \multicolumn{2}{|l|}{ NAT } \\
\hline & Negative (\%) & Positive (\%) & Negative (\%) & Positive (\%) \\
\hline HBsAg & 2048 (97.48) & $53(2.52)$ & $19(35.85)$ & $34(64.15)$ \\
\hline Anti-HBc & 1747 (83.15) & $354(16.85)$ & $320(90.4)$ & $34(9.6)$ \\
\hline Total & $2101(100)$ & & 2067 (98.38) & $34(1.62)$ \\
\hline Anti-HCV & 2094 (99.67) & $7(0.33)$ & $4(57.14)$ & $3(42.86)$ \\
\hline Total & $2101(100)$ & & 2098 (99.86) & $3(0.14)$ \\
\hline $\begin{array}{l}\mathrm{HIV} \mathrm{Ag/Ab} \\
\text { Combo }\end{array}$ & 2100 (99.95) & $\begin{array}{l}\text { Borderline } \\
1(0.05)\end{array}$ & $1(100)$ & $0(0)$ \\
\hline Total & $2101(100)$ & & $2101(100)$ & $0(0)$ \\
\hline Anti-HTLVI/II & 2097 (99.81) & $\begin{array}{l}\text { Borderline } \\
4(0.19)\end{array}$ & NA & NA \\
\hline CMV-IgG & $283(13.47)$ & $1818(86.53)$ & NA & NA \\
\hline CMV-IgM & 2094 (99.66) & $7(0.33)$ & NA & NA \\
\hline
\end{tabular}

tests at 6 months follow up were all negative.

\section{Human immunodeficiency virus (HIV)}

The viral markers tested in HIV were tested HIV Ag/Ab combo (reacting to both HIV p24 antigen and anti-HIV I/II) and HIV-NAT. There was one sample that showed an inconclusive result to anti-HIV I/II that also tested negative in HIV-NAT. This patient had previously indeterminate results to HIV-1/HIV-2 antibody during her antenatal care period and confirmation tests by Western blot and HIV RNA PCR were all negative. The case was classified as abnormally reacting plasma to HIV testing reagents.

\section{Human T lymphotropic virus $1 / 2$ (HTLV 1/2)}

(Table 2) No positive samples to anti-HTLV-1/HTLV-2 were detected but four were borderline. Confirmatory tests in reference laboratories were negative for all four.

\section{Cytomegalovirus (CMV)}

(Table 2) Positive results for CMV-IgG were seen in $86.53 \%$ (1818/2101). CMV-IgM positivity was seen in $0.33 \%(7 / 2101)$ while negative results were seen in $99.66 \%$ (2094/2101) respectively.

\section{Discussion}

In the present study, the prevalence of transmissible viral disease in Thai maternal samples of privately stored umbilical cord blood samples has been evaluated. To our knowledge, this is the first report in SE Asia in a similar setting. Various authorities have called for the harmonization of standards between public and private cord blood banks as differences in quality have been noted [13]. UCB banks offers an immediately accessible and valuable stem cell source for autologous and (related and unrelated) allogeneic HSCT with recognized lifesaving potential in a wide number of indications in hematological diseases, solid tumours, inherited or acquired diseases caused by deposits and immune disorders including autoimmune conditions $[1,4,16]$. Increasing use of preimplantation genetic diagnosis (PGD) with HLA matching in Thalassemia endemic regions as South East Asia will see the rise of subsequent related allogeneic cord blood stem cell transplantation both in Thalassemia [9] but also other hereditary conditions $[8,9]$. Increasing favourable evidence for the potential of autologous UCB in cerebral palsy [10-13], traumatic and/ or hypoxic brain injury $[14,15]$, diabetes $[6,7]$ and deafness $[6,7]$ may influence UCB banking $[16,17]$.

Hepatitis $B$ virus (HBV) infection remains a major global public health problem, despite the availability of a highly effective vaccine and improvements in antiviral therapy [18]. In Asia, especially SE Asian countries including Thailand, 8-15\% of the population are affected, with chronic liver disease, including chronic hepatitis, cirrhosis, and hepatocellular carcinoma as feared complications [18]. In Thailand, universal $H B$ vaccination of newborns was integrated into the national expanded programme on immunization since 1992 [19]. Our findings of $2.52 \% \mathrm{HBsAg}$ prevalence are lower than observed in Songklanagarind Hospital's antenatal clinic from 1995 to 2004 , the average prevalence rate of $\mathrm{HBsAg}$ there being $3.4 \%$ [20]. A discrepancy between $\mathrm{HBsAg}$ and anti-HBc prevalences were noted (16.85\% vs. $2.52 \%$ ) possibly be due to hepatitis B seroconversion or an undetectable residual virus. Further tests for anti-HBs were suggested to mothers and attending physicians to confirm a possible seroconversion. The prevalence of HBV-NAT was $1.62 \%$, lower than HBsAg, and no HBV-NAT positive/HBsAg negative samples were seen (implying recent infection or occult hepatitis $B$ infection). The reasons for the discrepancy between HBsAg and HBV-NAT 
Fongsarun et al. Transplantation Technology 2013,

may due to virus subtype, triple screening NAT or low viral load. Each NAT test was done individually, thus no false negative reactions from dilution effects were expected in our study. The low rates observed in our study may be due to the above mentioned universal $\mathrm{HBV}$ vaccination programme but also to the higher socioeconomic status of the UCB depositors [19,21].

Hepatitis $C$ virus (HCV) remains a large health care burden with a worldwide prevalence of about $3 \%$ estimated by WHO in 1999 [22]. Prevalence rates of 0.49\% in Japan [23] and $1 \%$ in China [24] have been reported with peaks in certain areas (30.13\% in Hubei province and $31.86 \%$ in Inner Mongolia Autonomous Region) $[\mathbf{2 5}, \mathbf{2 6}]$. In the present study, the prevalence of anti-HCV and HCV-NAT are $0.33 \%$ and $0.14 \%$ respectively compared to $2 \%$ previously reported in Thailand $[\mathbf{2 7}, \mathbf{2 8}]$. Four samples that reacted to anti-HCV test was negative for HCV-NAT and this discrepancy may due to HCV seroconversion or low viral load. Follow up HCV-NAT were advised to all anti-HCV positive/HCV-NAT negative mothers and repeat HCV-NAT tests at 6 months follow up were all negative suggesting seroconversion. There was no anti-HCV negative/HCV-NAT positive sample implying recent $\mathrm{HCV}$ infection in the present study. The low rates in general observed in our study may be due to the higher socioeconomic status of the UCB depositors.

With nearly 520,000 people (ages 15-49) living with HIV and AIDS, Thailand has the highest adult HIV prevalence in the South East Asia region but successful efforts in the past two decades have substantially reduced the number of annual new HIV infections [29]. The prevalence rate of HIV in Thai Blood donors in 2009 was $0.21 \%$ [30]. In the present study, one patient had previously indeterminate results of HIV-1/HIV-2 antibody during her antenatal care period and confirmation tests by Western blot and HIV RNA PCR were all negative. The case was classified as abnormally reacting plasma to HIV testing reagents. As all expecting mothers are tested antenally in their respective hospitals and our screening questionnaire clarifies that HIV positive UCB storage is declined, HIV positive cases opt out of UCB banking early, thus giving an overall HIV prevalence of $0 \%$.

Human T-lymphotropic virus (HTLV) types 1-4 are retroviruses that infect humans as a result of multiple episodes of cross-species transmission from different monkey reservoirs in Central Africa [31]. HTLV-1 is known to be the etiologic agent of two well-defined diseases, adult T cell leukaemia/ lymphoma (ATLL) and HTLV-1-associated myelopathy/ tropical spastic paraparesis (HAM/TSP). Although HTLV-2 has also occasionally been linked to neurological syndromes [31], the majority of carriers remain asymptomatic lifelong [31]. Prevalence rates of HTLV-1 infection in the general population are greater than 1\% in the Caribbean Basin, Central Africa, and South Japan [31]. In most other areas in the world, HTLV-1/2 infections are mainly found in high-risk groups (i.e., immigrants from endemic areas, their offspring, their sexual contacts, intravenous injection users and in patients attending sexually transmitted disease clinics) [31]. Blood donors are routinely screened for HTLV-1/2 in North America, several countries in Europe, Japan, and Taiwan [31]. The overall seroprevalence of HTLV infection among pregnant women in Spain is below $0.02 \%$ but increases to $0.2 \%$ with all cases found in immigrants from Latin America and Africa recommending antenatal screening in pregnant women coming from these regions [31]. In Thailand, two very early reports on HTLV 1 in blood donors and thalassaemia [32] as well as in pregnancy [33] are in accordance with our results of $0 \%$ prevalence. Four inconclusive results using anti-HTLV-1/ HTLV-2 screening tests were seen but the confirmation tests at reference laboratories were negative for all.

Cytomegalovirus (CMV) is one of the herpes viruses including the herpes simplex viruses, varicella-zoster virus, and the Epstein-Barr virus. Cytomegalovirus can cause serious disease in babies who were infected with CMV before birth (referred to as congenital CMV infection). Infants and children who are infected with CMV after birth rarely have symptoms or problems [34]. In Thailand, a CMV prevalence rate of $100 \%$ was reported in pregnant women [35] while in Thai blood donors the rate was $93.31 \%$ (males $91.53 \%$ /females $97.30 \%$ ) with only one positive CMV-IgM [36]. In the present study, the positive rate of CMV-IgG was $86.53 \%$, lower than reported in various Thai populations. Positive CMV-IgM was seen in $0.33 \%$ and all CMV IgM positive mothers and their physicians were informed in timely manner to ensure further investigation and management.

\section{Conclusion}

In the present study, in a Thai cohort of maternal blood samples of autologous UCB stored in a private cord blood bank, very low prevalence of transmissible viral disease was noted. HBV, $\mathrm{HCV}$, and CMV prevalence rates were lower than observed in the general Thai population, possibly due to widespread vaccine immunization, and the higher socioeconomic status of the mothers that opt for private UCB banking. Due to our screening procedures, HIV could not be detected in any of the maternal sera. HTLV 1/2 could not be detected in any of the samples and this is the first report of its prevalence in Thailand in almost 20 years. The low prevalence of CMV-IgM observed reinforces UCBs advantage in HSCT. The molecular biology techniques would make up for the default of the serological methods.
Abbreviations
UCB: Umbilical Cord Blood
HBV: Hepatitis B virus
HBsAg: Hepatitis B surface antigen
Anti-HBe: Hepatitis B e antibody
HCV: Hepatitis C virus
CMV: Cytomegalovirus
HIV: Human Immunodeficiency Virus
HTLV: Human T-lymphotropic
ATLL: Adult T cell leukemia/lymphoma 
Fongsarun et al. Transplantation Technology 2013,

HAM/TSP : HTLV-1-associated myelopathy/

tropical spastic paraparesis

HSC: Hematopoietic stem cells

HSCT: Hematopoietic stem cell transplant

NAT: Nucleic Acid Test

PGD: Preimplantation genetic diagnosis

GVHD: Graft-versus-host disease

\section{Competing interests}

The authors declare that they have no competing interests.

Authors' contributions

Juthatip Fongsarun has interpreted all results from all maternal samples while Mantana Paisan and Siripen Chanthachorn organized and performed maternal sample data collection from the files and together with Maneerat Ekkapongpisit offered technical assistance. All authored relevant parts of the manuscript. Konstantinos I Papadopoulos initiated the concept, design of the work, and critically revised and authored the final versions of the manuscript. All authors participated in all levels of the manuscript draft preparation and acknowledged the final version.

\section{Acknowledgement}

The authors wish to thank THAI StemLife and hospital nursing staff for the collection of the maternal samples as well as all mothers that stored their child's UCB with THAI StemLife.

\section{Publication history}

Editor: Elsie Maria Muller, University of Cape Town, South Africa. EIC: Stephen C Strom, Karolinska Institutet, Sweden.

Received: 12-Jul-2013 Accepted: 14-Aug-2013

Published: 27-Aug-2013

\section{References}

1. Sanchez-Guijo FM, Orfao A and Del Canizo MC. Bone marrow transplantation extends its scope. Adv Exp Med Biol. 2012; 741:121-34. | Article | PubMed

2. Locatelli F, Kabbara N, Ruggeri A, Ghavamzadeh A, Roberts I, Li CK, Bernaudin F, Vermylen C, Dalle JH, Stein J, Wynn R, Cordonnier C, Pinto F, Angelucci E, Socie G, Gluckman E, Walters MC and Rocha V. Outcome of patients with hemoglobinopathies given either cord blood or bone marrow transplantation from an HLA-identical sibling. Blood. 2013; 122:1072-8. | Article | PubMed

3. Gratwohl A, Baldomero H, Aljurf M, Pasquini MC, Bouzas LF, Yoshimi A, Szer J, Lipton J, Schwendener A, Gratwohl M, Frauendorfer K, Niederwieser D, Horowitz $\mathrm{M}$ and Kodera Y. Hematopoietic stem cell transplantation: a global perspective. JAMA. 2010; 303:1617-24. | Article | PubMed Abstract | PubMed Full Text

4. Blommestein HM, Verelst SG, Huijgens PC, Blijlevens NM, Cornelissen $\mathrm{JJ}$ and Uyl-de Groot CA. Real-world costs of autologous and allogeneic stem cell transplantations for haematological diseases: a multicentre study. Ann Hematol. 2012; 91:1945-52. | Article | PubMed

5. Ogawa M, LaRue AC and Mehrotra M. Hematopoietic stem cells are pluripotent and not just "hematopoietic". Blood Cells Mol Dis. 2013; 51:3-8. I Article I PubMed

6. Harris DT and Rogers I. Umbilical cord blood: a unique source of pluripotent stem cells for regenerative medicine. Curr Stem Cell Res Ther. 2007; 2:301-9. I Article I PubMed

7. Gluckman E, Ruggeri A, Rocha V, Baudoux E, Boo M, Kurtzberg J, Welte K, Navarrete $C$ and van Walraven SM. Family-directed umbilical cord blood banking. Haematologica. 2011; 96:1700-7. | Article | PubMed Abstract | PubMed Full Text

8. Kuliev A, Rechitsky S, Tur-Kaspa I and Verlinsky Y. Preimplantation genetics: Improving access to stem cell therapy. Ann N Y Acad Sci. 2005; 1054:223-7. | Article | PubMed

9. Manipalviratn S. Preimplantation Genetic Diagnosis for Thalassemia screening with HLA matching for cord blood stem cell/bone marrow transplantation. (abstract 0195) at the 23rd Asian \& Oceanic Congress of Obstetrics \& Gynaecology (AOCOG), Oct 20-23, 2013, Bangkok, Thailand.

10. Papadopoulos KI, Low SS, Aw TC and Chantarojanasiri T. Safety and feasibility of autologous umbilical cord blood transfusion in $\mathbf{2}$ toddlers with cerebral palsy and the role of low dose granulocyte-colony stimulating factor injections. Restor Neurol Neurosci. 2011; 29:17-22. Article | PubMed

11. Min K, Song J, Kang JY, Ko J, Ryu JS, Kang MS, Jang SJ, Kim SH, Oh D, Kim MK, Kim SS and Kim M. Umbilical cord blood therapy potentiated with erythropoietin for children with cerebral palsy: a double-blind, randomized, placebo-controlled trial. Stem Cells. 2013; 31:581-91. | Article I PubMed

12. Lee YH, Choi KV, Moon JH, Jun HJ, Kang HR, Oh SI, Kim HS, Um JS, Kim MJ, Choi YY, Lee YJ, Kim HJ, Lee JH, Son SM, Choi SJ, Oh W and Yang YS. Safety and feasibility of countering neurological impairment by intravenous administration of autologous cord blood in cerebral palsy. J Trans/ Med. 2012; 10:58. | Article | PubMed Abstract | PubMed Full Text

13. Sun J, Allison J, McLaughlin C, Sledge L, Waters-Pick B, Wease S and Kurtzberg J. Differences in quality between privately and publicly banked umbilical cord blood units: a pilot study of autologous cord blood infusion in children with acquired neurologic disorders. Transfusion. 2010; 50:1980-7. | Article | PubMed

14. Sun $T$ and $M a Q H$. Repairing neural injuries using human umbilical cord blood. Mol Neurobiol. 2013; 47:938-45. | Article | PubMed

15. Liao Y, Cotten M, Tan S, Kurtzberg J and Cairo MS. Rescuing the neonatal brain from hypoxic injury with autologous cord blood. Bone Marrow Transplant. 2013; 48:890-900. | Article | PubMed

16. Nietfeld JJ and Harris DT. Cost-effectiveness of private umbilical cord blood banking. Obstet Gynecol. 2010; 115:1090-1. I Article I PubMed

17. Badowski MS and Harris DT. Collection, processing, and banking of umbilical cord blood stem cells for transplantation and regenerative medicine. Methods Mol Biol. 2012; 879:279-90. | Article | PubMed

18. World Health Organization. Hepatitis B Fact sheet No 204. 2000. | Website

19. Chongsrisawat V, Yoocharoen $P$, Theamboonlers A, Tharmaphornpilas P, Warinsathien P, Sinlaparatsamee S, Paupunwatana S, Chaiear K, Khwanjaipanich S and Poovorawan Y. Hepatitis B seroprevalence in Thailand: 12 years after hepatitis $B$ vaccine integration into the national expanded programme on immunization. Trop Med Int Health. 2006; 11:1496-502. | Article | PubMed

20. Pradutkanchana S, Nasongkla K, Pradutkanchana J, Heembai U. A TenYear Trend of the Prevalence of Hepatitis B Surface Antigen in Pregnant Women at Songklanagarind Hospital. J Infect Dis Antimicrob Agents 2005; 22:111-114. | Pdf

21. Luksamijarulkul P, Mooktaragosa A and Luksamijarulkul S. Risk factors for hepatitis B surface antigen positivity among pregnant women. J Med Assoc Thai. 2002; 85:283-8. I Article I PubMed

22. WHO: Global surveillance and control of hepatitis C. Report of a WHO Consultation organized in collaboration with the Viral Hepatitis Prevention Board, Antwerp, Belgium. J Viral Hepat. 1999; 6:35-47. Article I PubMed

23. Tanaka J, Kumagai J, Katayama K, Komiya Y, Mizui M, Yamanaka R, Suzuki K, Miyakawa $Y$ and Yoshizawa H. Sex- and age-specific carriers of hepatitis $B$ and $C$ viruses in Japan estimated by the prevalence in the 3,485,648 first-time blood donors during 1995-2000. Intervirology. 2004; 47:32-40. I Article | PubMed

24. Wang Y, Tao QM, Zhao HY, Tsuda F, Nagayama R, Yamamoto K, Tanaka T, Tokita $\mathrm{H}$, Okamoto $\mathrm{H}$, Miyakawa $\mathrm{Y}$ and et al. Hepatitis $\mathrm{C}$ virus RNA and antibodies among blood donors in Beijing. J Hepatol. 1994; 21:634-40. I Article I PubMed

25. Zhang $Y Y$, Hansson BG, Widell A and Nordenfelt E. Hepatitis C virus antibodies and hepatitis $C$ virus RNA in Chinese blood donors determined by ELISA, recombinant immunoblot assay and polymerase chain reaction. APMIS. 1992; 100:851-5. | Article I PubMed

26. Tang $S$. [Seroepidemiological study on hepatitis $C$ virus infection among blood donors from various regions in China]. Zhonghua Liu Xing Bing Xue Za Zhi. 1993; 14:271-4. I Article I PubMed 
Fongsarun et al. Transplantation Technology 2013,

27. Ratanasuwan W, Sonji A, Tiengrim S, Techasathit W and Suwanagool S. Serological survey of viral hepatitis A, B, and C at Thai Central Region and Bangkok: a population base study. Southeast Asian J Trop Med Public Health. 2004; 35:416-20. I Pdf | PubMed

28. Sunanchaikarn $S$, Theamboonlers $A$, Chongsrisawat $V$, Yoocharoen $P$, Tharmaphornpilas P, Warinsathien P, Sinlaparatsamee S, Paupunwatana S, Chaiear K, Khwanjaipanich S and Poovorawan Y. Seroepidemiology and genotypes of hepatitis $\mathrm{C}$ virus in Thailand. Asian Pac J Allergy Immunol. 2007; 25:175-82. | Pdf | PubMed

29. National AIDS Prevention and Alleviation Committee: UNGASS Country Progress Report: Thailand, Reporting Period--January 2008 to December 2009. Published in 2010. | Website

30. Data from Thailand Health Profile 2008-2010. Bureau of Epidemiology, Thai Ministry of Public Health.

31. T Trevino A, Benito R, Caballero E, Ramos JM, Parra P, Roc L, Eiros JM, Aguilera A, Garcia J, Cifuentes C, Marcaida G, Rodriguez C, Trigo M, Arroyo LA, de Mendoza C, de Lejarazu RO and Soriano V. HTLV infection among foreign pregnant women living in Spain. J Clin Virol. 2011; 52:119-22. | Article | PubMed

32. Taechowisan T, Sutthent R, Louisirirotchanakul S, Puthavathana P and Wasi $\mathrm{C}$. Immune status in congenital infections by TORCH agents in pregnant Thais. Asian Pac J Allergy Immunol. 1997; 15:93-7. | Article | PubMed

33. Chiewsilp P, lamsilp W and Hathirat P. HTLV-I antibody screening in donated blood and thalassemic patients. J Med Assoc Thai. 1993; 76 Suppl 2:103-5. | PubMed

34. Center of Disease Control and Prevention: Cytomegalovirus (CMV) and Congenital CMV Infection. Available at | Website

35. Tantivanich S, Suphadtanaphongs V, Siripanth C, Desakorn V, Suphanit I, Phromin S, Panakitsuwan S and Amarapand P. Prevalence of cytomegalovirus antibodies among various age groups of Thai population. Southeast Asian J Trop Med Public Health. 1999; 30:265-8. I PubMed

36. Urwijitaroon Y, Teawpatanataworn S and Kitjareontarm A. Prevalence of cytomegalovirus antibody in Thai-northeastern blood donors. Southeast Asian J Trop Med Public Health. 1993; 24 Suppl 1:180-2. I PubMed

\section{Citation:}

Fongsarun J, Ekkapongpisit M, Paisan M, Chanthachorn $S$ and Papadopoulos KI. Prevalence of transmissible viral disease in maternal blood samples of autologous umbilical cord blood in a private cord blood bank. Transplant Technol. 2013; 1:1.

http://dx.doi.org/10.7243/2053-6623-1-1 